\title{
THE UNIT OF OFFENSE IN FEDERAL STATUTES
}

At the present time there is pending in the Supreme Court of the United States a case involving a rather narrow point, but one that has been occupying the attention of the Fecleral Courts a great deal of late. What shall be treated as the "unit of offense" under the Twenty-Eight Hour Law, the Anti-Rebate Act, and a number of other Federal statutes where Congress has not been specific and precise in limiting and defining the penalty?

An examination of the cases on separable offenses, repeating offenses, etc., "presents contradictions quite irreconcilable," as Mr. Bishop points out, ${ }^{1}$ and there is no great help to be derived in construing these Federal statutes from such general rules as that a penal statute must be strictly construed, for generally there is little or nothing to construe, and as to this particular rule, it cannot be said that it is regarded with much favor at the present time, either by the Courts or by the general public.

The case referred to as now pending is Baltimore \& Ohio Southwestern R. Co. v. U.S., ${ }^{2}$ which comes before the Supreme Court under what is known as the Twenty-Eight Hour Law. This statute provides that no carrier shall confine cattle in cars or vessels for longer than twenty-eight consecutive hours without unloading, except that upon the request of the owner or person having charge of a particular shipment the time may be extended to thirty-six hours. .The penalty imposed is "for every failure," but the act nowhere states just what is meant by failure, with the natural result that the Government is contending that the unit of offense is the separate shipment, and the shippers asserting just as positively that it is the train, no matter of how many separate shipments composed, or, at any rate, that it is something other than the shipment.

The case has been once argued in the Supreme Court, and as the court found itself equally divided, a motion for re-argument has been granted, and the case set for October, 1910.

The briefs of opposing counsel are interesting, but rest almost entirely on statutory construction. The main argument of the

1 I Bish. New Cr. Law sec. 106r.

2 Reported below, 159 Fed., 33 .

${ }^{3} 34$ St. at L. 607 . 
late Solicitor-General Bowers is to this effect: It would be impossible to give any reasonable interpretation to the proviso that the owner of any particular shipment may consent to an extension to thirty-six.hours if the train were to be taken as the unit, for that would lead to the dilemma that all shippers in the train must consent before any shipment can be confined thirty-six hours, or any shipper can extend the time to thirty-six hours for all, or, finally, that although the train is the unit, part of it may be governed by the twenty-eight hour provision and part by the thirty-six hour provision. This argument, under the wording of the Act, seems unanswerable, but the railroad takes this ground:

Live stock is moved by trains. Now, if this is a confinement beyond the lawful period, then it must be the fault of the train. Congress must have intended that the penalty should be imposed according to the way live stock is moved-and that is by trains, not by shipments. The Government's answer to this line of reasoning seems convincing: the shipment is the unit as to which the carrier's conduct is prescribed by statute, and it must equally be the unit of the carrier's misconduct through violation of the prescribed rule of conduct concerning the shipment.

In the trial of this case in the Circuit Court of Appeals for the Sixth Circuit, the Government won its contention." The Court based its decision chiefly on the right of an individual shipper to have the time extended to thirty-six hours. The inconvenience to the railroad in dropping and picking up cars in order to comply with the law did not impress the court "as being very persuasive, although if the matter were very doubtful it would deserve to have some weight." This case has "been followed in the First -Circuit, ${ }^{8}$ in the Second .Circuit, ${ }^{\circ}$ and in the Circuit Court for the District of Oregon. ${ }^{7}$ In $U . S . v$. Southern Pac. Co., ${ }^{8}$ a case in the District Court for the Northern District of California, De Haven, D. J., charged the jury that each separate shipment constituted a separate offense. Judge Landis, in U.S. v. A., T. \& $S$. F. $R y . C o .{ }^{9}$ refused to consider as precedents the rulings of other courts in the rebate cases which had held that there were only as many offenses as there were back payments by the railroad company to the shipper, stating that he did not believe the

159 Fed., 33.

U. S. v. N. Y. C and H. R. R. Co., I65 Fed., 833.

- U. S. v. N. Y. C. and St. L. R. Co., 169 Fed., 699.

TU. S. v. Oregon R. and Nav. Co., 163 Fed. 642.

I57 Fed., 459, 463.

- I66 Fed., 160, 164. 
Supreme Court would sanction that doctrine, and he decided that each shipment was a separate offense.

These cases seem to be all the anthorities under the TwentyEight Hour Law, and it is believed that the Supreme Court will uphold their unanimous rulings. It certainly is a grave defect in a statute that in order to determine whether an offender shall be liable to a fine of $\$ 100$, or many times $\$ 100$, the Court must turn to a brief proviso, not directly relating to the penalty, as the "one salient expression upon which we can lay hold with confidence." 10

The cases of greatest popular interest raising the question of the unit of offense are those under the Anti-Rebate Law, the chief of which is U.S. v. Standard Oil Co. The provision of law which is here concerned is as follows:

"And it shall be unlawful for any person, persons, or corporation to offer, grant, or give or to solicit, accept, or receive any rebate, concession or discrimination. Every person or corporarebate, concession or discrimination. any such rebates, concession or discrimination shall be deemed guilty of a misdemeanor..." 11

It may be well to enumerate the principal propositions as to what is the unit of offense under this statute, as asserted by counsel or laid down by judges, in the various Standard Oii cases, and comment briefly on each.

(I) An agreement to give rebates for a specific period constitutes one offense for all of that specific period. ${ }^{12}$ This contention is easily disposed of by Judge Landis when he states that the parties cannot limit their liability by an agreement to disregard the law for a long period of time. Certainly it would be a strange anomaly for the offender to have the power to "capitalize offenses," to use a phrase of Judge Hough's, ${ }^{13}$ in such a manner that the Government must wait patiently through a long series of years until the illegal agreement expired before having a right to prosecute; or else to prosecute once, and thereafter stand idly by while the carrier continues its rebates and concessions as part of its original offense for which, so to speak, it has made payment to the Government in advance.

(2) A separate car load. constitutes a separate shipment. ${ }^{14}$ This was the theory on which the fine of $\$ 29,240,000$ was im-

10 U. S. v. B. and O. S. W. R. Co., I59 Fed., 33, 36.

1132 Stat. at L. 847, Sec. I.

12 Argument of defendant, 155 Fed. 305, 313. .

13 U. S. v. G. N. Ry., 157 Fed., 288, 291.

14 Landis, D. J., 155 Fed., 305, 313, 314. 
posed. There seems no getting around the statement of the Circuit Court of Appeals that the car load as the unit was "wholly arbitrary-had no basis in any intention or fixed rule discoverable in the statute." ${ }^{\text {"s }}$ Judge Landis, in the Court below, made this statement:

"As the Court reads this enactment, the offense is complete whenever any' property is transported at less than the lawful rate. If this be true, the law is violated every time any property is so transported."

Now, why should the learned Judge interpret "any property" as meaning "car load," rather than one pound, or one gallon, or one train load, or the total amount transported in one year? The fact is the Act named no unit of measurement of this nature, and any one that is laid down is simply a guess as to what Congress intended.

(3) Each shipment upon which a concession is given constitutes a separate offense. ${ }^{10}$

(4) The number of penalties should be limited to the number of bills presented by the carrier and paid by the shipper, the offense being complete when the money is paid. ${ }^{12}$ This third view would, to the writer's mind, be the correct one where the offense charged was merely soliciting or agreeing to accept a rebate or concession, but in the Standard Oil cases the indictment charged not an agreentent to accept, but an actual acceptance of a rebate, and, as the Circuit Court of Appeals points out, ${ }^{18}$ until the transaction has been consummated by the payment by the shipper of the less rate, or the receipt of the shipper from the carrier of a -rebate on the full rate, there is no completed offense. Accordingly it would seem that the fourth view is correct, viz.: that the number of payments would indicate the number of offenses. It might be argued that we have arrived at the same situation as objection was made to above-the carrier could arrange for very few payments at very long intervals. But from a practical standpoint this is not probable, and if it was, there is no necessity for indicting for the completed offense, when the Act makes the soliciting or agreeing to accept a rebate or concession equally an offense.

\footnotetext{
${ }^{15} 164$ Fed., 376, 386.

16 Hazel, D. J., I58 Fed., 536, 538.

${ }^{17}$ Contention of defendant, 155 Fed., 305, 313, decision of Circuit Court of Appeals, 16, Fed., 376, 385, 386.

${ }^{18}$ 'I64 Fed., 376, 386.
} 
Outside of the Standard Oil cases, there are a number of interesting decisions on the Anti-Rebate Act, particularly two by Judge Hough in the Southern District of New York; made prior to the Circuit Court of Appeals decision. In $U$. S. v. Great Northern R. Co., ${ }^{19}$ and $U . S$. v. Central Vt. Ry., ${ }^{20}$ the learned Judge took the view that a rebate is not given until the amount thereof is paid- "if a man agrees to give another an unlawful pecuniary advantage, something not enforceable at law at all, it appears to me plain that the person to whom the promise is made has gotten nothing whatever until he has received and pocketed the pecuniary fruits of such illegal arrangement." "If . . . the payment and acceptance of the rebate be the substantial offense here charged, then I think each substantial payment is properly the subject of separate indictment or count, just as truly as each separate and distinct visit of a burglar to a chest he slowly rifles of a set of silverware constitutes a separate offense, although it was his original intention to take the entire set sooner or later." Two successive cases in 165 Fed. Rep. are to the same effect: U.S. v. Stearns Co., ${ }^{21}$ and U. S. v. Bunch, ${ }^{22}$ and they are interesting as throwing some light on the question as to what-would be the rule in case the indictment charged merely an offering or soliciting of a concession or rebate. Judge Knappen, in the first named case, thought that the Circuit Court of Appeals' decision "apparently favors the proposition that even in such case the offense is not committed until the payment and receipt of the rebates"; and a careful reading of Judge Grosscup's opinion and of Judge Baker's concurring opinion does seem to indicate, by way of dicta, that payment and receipt are necessary in every case. If that was meant, said Judge Trieber in $U . S$. v. Bunch, such an interpretation violates the maxim that "all the words of a law must have effect rather than part should perish by construction," and he quotes authorities which, to the writer's mind, point strongly to the fact that payment would not be necessary in case only an offer or solicitation were charged in the indictment. ${ }^{23}$

There is little to indicate what view the Supreme Court of the United States will take as to the unit of offense in these rebate cases. They have said, with respect to the right to prosecute in

19157 Fed., 288.

20187 Fed., 291.

21 165 Fed., 735 .

22165 Fed., 736 .

${ }_{23}$ See Armour Packing Co. v. U. S., 209 U. S., 56, 73, 74. 
each of the districts through which goods are transported at an illegal rate, that such a transportation is a single offense, although it is continuously committed in each district in which the transportation is received at the prohibited rate. ${ }^{24}$ But aside from this statement, the Court has not been called upon as yet to pass on this phase of the rebate law, nor has it indicated otherwise what its decision will be.

A third class of cases of much importance at the time, but now chiefly of historical interest, arose under the Anti-Polygamy. Act of $1882,{ }^{25}$ which provided that "if any male person ... cohabits with more than one woman, he shall be deemed guilty of misdemeanor." In the case of In re Snow, 26 the defendant was convicted of three separate offenses under this statute by reason of cohabitation during a certain period with seven women as his wives. The Supreme Court held that there was but one offense, that "it was the mere will of the grand jury" that stopped with three offenses rather than thirty-five, or more, that this was one of the class of offenses that were continuous in character and not of the class that can be committed urno ictu.

The inherent difficulty in all these cases arises from the fact that it is quite impossible to determine whether Congress is laying more emphasis on a guilty state of mind-the mens rea of the criminal law-or on the overt act resulting from that state of mind. Of course, every real crime contains both elements, and if either element is missing there is no crime. What is one act is perhaps a simple enough thing to determine, but what is one state of mind is not so simple. If the A railroad, in accordance with a previous agremeent with the $B$ company, knowingly transports one car of coal each day during the month of May at a rate forbidden by law, has the $A$ railroad committed thirty offenses, or one offense, or some intermediate number? The A railroad may argue that it formed the intention to give this concession to the B company on the last day of April preceding, and never varied from that intention during the whole of May, nor formed any new intention-in other words, that there was only one state of mind during all that period, and when punished once, there can be no second punishment. The prosecution, on the other hand, may take the view that every time a car is shipped, there is a

24. Armour Packing Co. v. U. S., 209 U. S., 56, 77.

2522 Stat. at L. 31 .

26120 U. S. 274. 
new state of mind, a new mens rea, and therefore there were thirty acts accompanied by thirty punishable states of mind, and so thirty crimes.

If the law should disregard the state of mind, there would be no question but that every act was a separate offense-thus, if I drive my automobile at an illegal rate of speed on thirty consecutive days, I certainly would commit at least thirty distinct offenses. But this would be a case of that class where the law regards presence or absence of intent as immaterial-offenses which an eminent teacher is accustomed to term to his classes "public torts," i. e., acts where the gist of the liability is the damage done to the public and not the wrongful state of mind of the doer. However, intent must be taken into account in the classes of cases we have been discussing, because they are true crimes; and unless Congress more specifically declares what shall constitute one entire and completed crime in offenses, particularly in offenses concerned with interstate commerce, the Courts will probably be called on for repeated constructions that a little care in drafting would have made unnecessary.

While the question of the unit of offense seems only to have arisen under these three or four statutes, there is no reason why it may not come up under a number of other Federal statutes. Thus under the Animal Quarantine Act, ${ }^{27}$ the penal section (sec. 6) merely provides that "any person, company, or corporation violating the provisions of section two or four" shall be punished, without any statement as to whether the unit is one cow, one shipment, one train, one boat load, etc.; the Pure Food and Drugs Act $^{28}$ provides against the adulteration of "any article of food or drugs," and it might be contended that because it speaks of "original packages" an original package is the unit; however, section ten speaks of "any article . . . in originai unbroken packages," which seems to point to an entire shipment as included in "any article"; the Eight-Hour Law ${ }^{20}$ might be construed to make the employer liable for one offense for each and every employee working over eight hours, or only for one offense for all his employees working over-time on one separate day.

It is needless to multiply further such examples. These statutes affect interests of such importance that it is known before

${ }^{27} 33$ St. L. 1264.

${ }^{28} 34$ St. L. 768.

2027 St. L. 340. 
they are enacted that every doubtful word or phrase will be subject to question and argument, and it is confidently believed that if the unit of offense were defined with precision and certainty much of the difficulty of their enforcement would disappear.

New York City.

\section{F. Granville Munson.}

